\title{
Fostering Technological Entrepreneurship for Socioeconomic Development: A Case for Technology Incubation in Bayelsa State, Nigeria
}

\author{
Gordon M. Bubou (Corresponding author) \\ National Centre for Technology Management, (Federal Ministry of Science \& Technology) \\ South-South Zonal Office, Niger Delta University \\ Wilberforce Island, Amassoma \\ P.O. Box 1237 Yenagoa, Bayelsa State, Nigeria \\ E-mail: gordon.bubou@nacetem.org, blossom_bibi@yahoo.com \\ $\&$ \\ Institute of Engineering, Technology and Innovation Management (METI) \\ Centre for Engineering and Technology Management (CETM), University of Port Harcourt \\ Port Harcourt, Nigeria \\ E-mail: gbubou@gmail.com
}

Festa N. Okrigwe

National Centre for Technology Management, (Federal Ministry of Science \& Technology)

South-South Zonal Office, Niger Delta University

Wilberforce Island, Amassoma

P.O. Box 1237 Yenagoa, Bayelsa State, Nigeria

E-mail: gordon.bubou@nacetem.org, blossom_bibi@yahoo.com

Received: September 15, $2011 \quad$ Accepted: October 11, $2011 \quad$ Published: December 1, 2011

doi:10.5539/jsd.v4n6p138

URL: http://dx.doi.org/10.5539/jsd.v4n6p138

\begin{abstract}
There is an observed dearth of technological entrepreneurship across Africa, worse still, the Niger Delta region (NDR) of Nigeria. Entrepreneurship generally and technological entrepreneurship in particular are now considered as the engine for economic development. Technology-business incubators (TBI) are seen as a means of tackling developmental challenges. Most developed and emerging economies and developing countries have adopted TBI to fast-track the creation of new technology-based enterprises because of its more than $80 \%$ success rate of new venture creation, and have consequently benefited from its multiplier effects such as technology/knowledge transfer, employment generation and wealth creation. In the light of lack of data on incubation activities in Africa, more so for Nigeria, the paper highlights the contributions of TBIs to regional development. This to draw attention of stakeholders in the Yenagoa Technology Incubation Centre which will contribute to the socioeconomic and technological development of the State and NDR, by promoting technological entrepreneurship, eradicating poverty, enhancing Nigeria's technological capability, thereby ultimately reducing her reliance on petroleum resources.
\end{abstract}

Keywords: Technology-business incubator, Business incubators, Regional development, Technology commercialisation, Entrepreneurship, Yenagoa technology incubation centre, Sustainable development, Bayelsa State, Nigeria, Africa

\section{Introduction}

There is an apparent dearth of science and technology entrepreneurship capital in Africa, a situation that has led to the near non-existent productive capacity of the continent, with very minimal potentials for value addition (Bubou \& Siyanbola, 2010). The result of the foregone scenario is low capacity for wealth creation and 
increasing levels of unemployment. Similarly, there is lack of entrepreneurialism in the Niger Delta region of Nigeria, more so, Bayelsa State (Bubou \& Egai, 2010). However, there is compelling evidence that entrepreneurship (especially technological entrepreneurship) and innovation (technological innovation) are the twin pillars of socioeconomic development in this modern era.

Development experts, professionals from the academia and the business world as well, have been proffering all kinds of strategies to solve the problems of Africa's technological underdevelopment which is the bane of her socio-economic woes. In today's globalised world that has largely become knowledge/technology driven, it may not be an overstatement to say that technology-business incubators (TBIs) hold the key to Africa's much touted technological advancement and socio-economic development. The reason is that TBIs will facilitate technology/knowledge transfer. The same can be said of Nigeria and by extension, Bayelsa State.

As industrialised as Europe is, the European Union (EU) believes that one key factor for achieving the 'Lisbon 2000' strategic goal of becoming the world's most competitive and dynamic knowledge-based economy was the emergence of an enterprise culture in Europe and that EU's future depends largely on a healthy business birth rate, increased business survival and a successful small business sector (Folinas et al., 2006). New business creation is recognised as a critical element in sustainable economic growth with knowledge based businesses having been afforded priority in many ways through evolving government policies in the UK (Barrel, 2004). For instance, the National Technology Incubator's Network of Australia (NTIN, 2009) argues that business incubators (BIs) that support the development of technology based companies are an important contributor to the Federal Government's goal of refocusing Australia's economy towards one founded in the knowledge based industries.

In citing Juma and others (2001), the UN Millennium Project (2005) stated that development trends around the world need to be reviewed to evaluate the role that science, technology and innovation play in economic transformation in particular and sustainable development in general. But that a nation's ability to solve problems, initiate and sustain economic growth depends partly on its capabilities in science, technology and innovation (UN Millennium Project, 2005). Similarly, a country's competitiveness as well as the economic performance of industry is determined by technological capability (Raghavendra \& Bala Subrahmanya, 2006). Thus far, investments and incentives to grow them (incubators) have been minimal or nonexistent in most developing countries, including Nigeria, and the focus of government and foreign investment have been largely on infrastructure and industrial projects (UN Millennium Project, 2005).

However, because technology-driven and knowledge-based developments not only exhibit tremendous business potential, but also offer a range of innovative applications beneficial to various sectors of the society (Khanduja, et al., 2008), the concept of technology-business incubation has been adopted by the developed countries, most emerging and developing economies in order to maximally harness their potential benefits. This provides the needed strategy to generate technology-based businesses and ultimately enhance higher levels of socio-economic development. Incubator impact when assessed along the establishment of new technology based ventures that create high value jobs, generation of local and export income and leveraging broader economic activities is quite profound (NTIN, 2009).

Unfortunately, nearly all developing countries including Nigeria are often characterized as producers and exporters of a few types of natural resource based goods, whereas intuition dictates that these countries should change their strategy from being merely merchandise producers to technology developers in order to experience higher levels of development (Mellati, 2008). The involvement of developing countries in producing new technologies and innovations is almost negligible (Juma \& Agwara, 2006).

This therefore, calls for application of the concept of technology-business incubation to enhance the technological and socio-economic development of regions and countries within the developing world. On this note, Bayelsa State of Nigeria, which is one of the poorest by all known indicators of poverty despite being in the mist of rich petroleum resources, should support the Yenagoa TIC in order to enjoy the benefits derivable from TBIs.

\subsection{Brief historical perspective}

The Batavia Industrial Centre, commonly known as the first United States (US) business incubator, in Batavia, New York in 1959 (National Business Incubation Association - NBIA, 2009) which was opened by Joseph Mancuso is said to have marked the formal beginning of the concept of business incubation. Nevertheless, the concept of providing business assistance services to early-stage companies in shared facilities did not catch on with many communities until at least the late 1970s (NBIA, 2009). Such initial incubation efforts included the establishment of managed workspaces, enterprise agencies, industrial estates, science parks and enterprise 
centres, which emerged from 1970s to 1980s with the specialized incubator (for example, technology-business incubator) only appearing in the subsequent decade (Folinas et al., 2006). BIs expanded in the US in the 1980s and spread to the United Kingdom (UK) and Europe through various related forms, vis-à-vis - innovation centres, pépinières d'entreprises, technopoles/science parks (Wikipedia, 2009). See Figure 1 for the evolution of TBI.

From observations, TBI may have emerged from central government schemes rather than from local public-private initiatives in newly industrial and transition economies (UN Millennium Project, 2005). High-technology incubators responsible for creating wealth and jobs worldwide have been particularly successful in the US, Israel and China as incubators reduce the business failure rate by providing quality training and guidance to such companies in the initial stages (Khanduja et al., 2008).

By nurturing SMEs' (Juma \& Agwara, 2006; Oyelaran-Oyeyinka \& Lal, 2006; Stefanovic et al., 2008) and especially technology-based SMEs (Kark, 2003) through the concept of TBIs, most countries have improved their economies and perhaps moved a step closer to development. Such countries include China, Korea and India. For instance, BIs have become a vital part of the Korean venture eco-system (Kim \& Ames, 2006). Another example is the case of India. Given her obvious challenges, India country made deliberate efforts to encourage entrepreneurship, education, training and research (Khanduja et al., 2008). This was geared together to foster relevance, competence and excellence in establishing TBIs all over the nation, making her what she is today (Khanduja et al., 2008).

NBIA (2008) estimates that there are about 7,000 business incubators worldwide with North America having about 1, 400 up from just 12 in 1980. It is estimated that Europe too has nearly the same number as North America, with the highest concentration found in Finland, Germany, Sweden and the UK (Stefanovic et al., 2008). Among the developing countries, China has the largest number of incubators (over 550 for all types of companies) being second the US (Ma, 2004; Southwood, 2004) and the overall number in developing countries is beginning to catch up with the developed world number (Southwood, 2004). Korea has about 350 as at 2002, while Japan, Malaysia, India and Singapore are catching up vigorously (Kim \& Ames, 2006). According to the Federal Ministry of Science and Technology 'FMST' (2005), Nigeria has about 21 Technology Incubation Centres. However, an incubator expert Knopp (2007) states that technology incubators account for about $39 \%$ of all incubator programmes worldwide.

\subsection{Origins of technology incubators in Nigeria}

The origin of technology-business incubators in Nigeria can be traced to 1993 when the first technology incubation centre (TIC) was commissioned in Agege, Lagos. However, a formal programme of technology incubation in the country was only launched with the promulgation of Decree No. 5 of 1995 which also entrusted the supervision and coordination of the programme to the Federal Ministry of Science and Technology with effect from July, 1995 (FMST, 2005). At the last count, there are a total of 21 TICs spread across all the parts of Nigeria with the Federal Government intending to establish at least one in each of the 36 states of the federation.

The most recent of the incubators to be established in Nigeria is the Yenagoa Technology Incubation Centre. Though the incubator management staffs have been commissioned to start work, it is yet to start off because partners to the counter-part funding arrangement have failed to make their commitments.

The objective of this paper is to take stock of the historical origins and the evolution of the business incubation concept, underscore the contributions of TBIs to socioeconomic development, and last to draw attention of all stakeholders to the Yenagoa TIC. Consequently, the subsequent sections provides a conceptual framework, TBIs and socioeconomic development, the methodology adopted for the research, the Yenagoa TIC, and lastly, the conclusion.

\section{Conceptual framework}

\subsection{Technology business}

Technology (-based) businesses can be referred to as businesses that engage in technology related products, processes and services. They may be low-, medium- or high-technology. One area of the economy which has seen significant growth is that focused on new technology-based products and services and the high-technology sectors are perceived as major sources of future economic prosperity and employment growth (Cooper, 2006). Some of such high-technologies include nano-technology, bio-technology, ICT, etc.

\subsection{Business incubators}

Incubators generally differ from research and technology parks in their dedication to start-up and early-stage companies because research and technology parks, tend to be large-scale projects that house everything from 
corporate, government or university labs to very small companies and may even house an incubator (Wikipedia, 2009). Business incubation is a dynamic process of business enterprise development (Stefanovic et al., 2008). According to Kim and Ames (2006), the definition of business incubators can differ by researchers' points of view. On the other hand, the most basic concept is the 'incubator' - maintenance of controlled conditions that are useful for the growth and development of start-up companies. Business incubators aim to assist entrepreneurs with enterprise start-ups and development. Likewise, BIs aim to maximise the chances of success of start-up companies by creating a supportive environment (Stefanovic et al., 2008). Finally, incubators typically seek to provide workspace, often on preferential and flexible terms, for specific industries or types of firm (Kim \& Ames, 2006; Stefanovic et al., 2008).

NBIA (2008) defines a business incubator as an economic development tool designed to accelerate the growth and success of entrepreneurial companies through an array of business support resources and services by nurturing the development of entrepreneurial companies, helping them survive and grow during the start-up period, when they are most vulnerable. BIs provide not only basic services such as inexpensive space, but also provide various services to tenant firms in early stages to effectively connect abilities, technology, capital, know-how of entrepreneurs, thereby promoting development of start-ups and transfer of technologies (Kim \& Ames, 2006).

Business incubators or holding companies that provide funding, technical support and networking capabilities, have become central to the development of early stage businesses in Western countries (Klonowski, 2007). Typically, this involves offering management assistance, mentoring, access to financing, flexible and low-cost leases, office services (Stefanovic, 2008). TBIs, popularly called Technology Incubators (TIs), are offshoots of business incubators. Likewise, business incubators promote the development of new and qualified SMEs (UN Millennium Project, 2005) by providing qualifying new start-up businesses with a set of facilities - physical space, shared services, business and legal advice and financial inputs - to facilitate their creation and assist them until 'graduation', when they have the capacity to 'survive' in the outside competitive environment thereby improving their chances of success (UN Millennium Project, 2005; Folinas et al., 2006 as cited in Autio \& Klofsten, 1998; Hannon, 2004). The business incubation process adds value by accelerating the start-up of new businesses and helping to maximize their growth potential in a way that is more difficult for alternative SME support structures to achieve (Stefanovic et al., 2008). Folinas et al. (2006) opined that one of the key determinants for the growth of an entrepreneurial society is the empowerment of private initiatives and the nurture of new enterprises on their way to sustainability and that one of the mechanisms employed to nurture small firms for the past two decades is the business incubation approach. Accordingly, incubators have become increasingly popular in the industrialized world and in developing countries

\subsection{Technology-business incubators}

Expectedly, newly started firms are often very vulnerable with most young high-tech companies encountering and having to cope with a multiplicity of challenges. Therefore, most countries and regions have organisations that provide support to assist these companies overcome their challenges (Kirwan et al., 2008). One of the means young high-tech companies receives such support and assistance is through the tutelage in a TBI.

According to the UN Millennium Project (2005) Technology incubators are a special type of business incubators that focuses on new ventures that employ advanced technologies. However, even though technology incubators share the same general goals as business incubators, they focus more on the commercialization and diffusion of technology by new firms. They nurture hi-tech start-ups and present a technology -oriented variant of business incubators (Stefanovic et al., 2008). However, the first requirement for creating a successful technology-based firm is the existence of a good business idea with a good market potential, to be converted into a new product or service by an entrepreneur (Folinas et al., 2006). It seeks to effectively link talent, technology and know-how to leverage entrepreneurial talent in order to accelerate development of new companies and speedy commercialisation of $\mathrm{R} \& \mathrm{D}$ and innovation. It also helps in value re-orientation by creating an environment for changing the attitudes towards personal initiative, innovation, risk-taking and entrepreneurship.

\section{Technology-business incubators and socioeconomic development}

Science, technology, innovation entrepreneurship has been proven, not only to be the impetus for growth and economic prosperity, but also serves as the foundation for the transformation of the new economy (Sankat, 2010). Within the last decades, entrepreneurship has ascended to the centre stage in the public policy arena of most countries as reflected in several major policy initiatives around the world (Reynolds et al., 1999). However, moving technology from the scientific discovery stage to a commercially successful product is one of the major drivers of economic development in today's world order (Jordan et al., 2006). This is most vital thing to 
sustainable development and it can only be effectively done by technopreneurs. Such technopreneurs can be groomed in a TBI.

Before about 1980, the vast majority of research on technology transfer focused on cross-national technology transfer, especially the transfer of technology from industrialized nations to less developed nations (Bozeman, 2000). However, TBIs present the leeway to reverse that situation as they stimulate innovation and entrepreneurship culture resulting in the emergence of new technologies and structures that enhance nations' competitiveness as well as fostering local and regional economic development (FMST, 2005). In addition, TBIs revitalise neighbourhoods, strengthen local, regional and even national economies as well as serving as an investment vehicle (NBIA, 2008). Not only that, they also help in diversification of the local economies (NBIA, 2008; Knopp, 2007; UN Millennium Project, 2005).

BIs have proven to be effective tools for promoting economic growth throughout the world is considered as flexible economic development tool (NBIA, 2008) as they serve as catalysts in the process of starting and growing companies by providing entrepreneurs with the expertise, networks, and tools needed to make their ventures successful (Grimaldi \& Grandi, 2005). BIs generally and BTIs in particular contribute to the economic development of a country through creation of new companies, increased employment or job generation, improvement of industry structure, acquisition, commercialisation and/ or transfer of technology owned by universities and research institutions, wealth creation, and the promotion of techno-entrepreneurship culture (FMST, 2005; Kim \& Ames, 2006; NBIA, 2008; UN Millennium Project, 2005; Khanduja et al., 2008; Stefanovic et al., 2008).

Knopp (2007) sums it up that the concept of business incubation, be it technology or otherwise was conceived as a means of meeting a variety of economic and socioeconomic policy needs that included the following: -

- Creating jobs and wealth;

- Fostering a community's entrepreneurial climate;

- Technology commercialization;

- Diversifying local economies;

- Building or accelerating growth of local industry clusters;

- Business creation and retention;

- Encouraging women or minority entrepreneurship;

- Identifying potential spin-in or spin-out business opportunities; and

- Community revitalization.

In specific terms, NBIA estimates that in 2005 alone, North American incubators assisted more than 27,000 start-up companies that provided full-time employment for more than 100,000 workers and generated annual revenue of more than $\$ 17$ billion with a reported $87 \%$ of all firms that have graduated from their incubators are still in business (NBIA, 2008). Establishment of UK Incubation - national organisation, and support through regional funding of a large number (more than 300) incubators and innovation centres (Barrel, 2004) Chinese models have been very successful in accelerating the growth of economy and have influenced the incubation process in the neighbouring nations (Khanduja et al., 2008).

\section{Methodology}

This is conceptual paper and it adopted the methodology of the case study exploratory approach. The paper therefore, takes after the methodology suggested by Cooper and Schindler (2003) that exploratory research mainly uses secondary data from extant literature to underpin the theoretical and contextual frameworks of technology-business incubation. This was also predicated upon the lack of adequate information on the activities of business or technology incubators in Nigeria, more so, in Bayelsa State.

However, as expected, the researchers also used qualitative inductive reasoning to draw inferences for this work which is the hallmark of exploratory case studies. This is a position supported by many other researchers (Cooper \& Schindler, 2003; Page \& Meyer, 2000; Saunders et al., 1997).

Based on the findings from the exploratory studies on the extant literature, an appraisal of the Yenagoa Technology Incubation Centre was made to ascertain the extent to which it will contribute to the socio-economic development of the host region, its level of achievement, funding requirements, the networks of higher institutions that will participate in the incubator as well as the challenges that may impede its early take-off and proper functioning. 


\section{The Yenagoa Technology Incubation Centre}

As it where to affirm the statements of Cooper (2006) and the UN Millennium Project (2005) that most technology incubators emerged from central government schemes rather than from local public-private initiatives, the Yenagoa TIC was the brainchild of the Federal Government of Nigeria, through the FMST. The policy thrust of the Technology Incubation Programme (TIP) in Nigeria is to pursue the commercialisation of technologies and technical innovations using technology incubation as tool in order to enhance the attainment of technological, industrial, social and economic competitiveness of the country and improve the quality of life of its citizens (FMST, 2005).

Technology incubators aim mainly to build bridges between academia and industry, promote innovation in small and medium-size enterprises, and encourage investments in technology-based start-up firms (Cooper, 2006). Because higher education and research institutions integrate into the production sector and into society in many ways by conducting R\&D for industry, creating their own spin-off firms, are involved in capital formation projects, TBI facilities introduce entrepreneurial training; and encourage students to transform research into enterprises (Juma, 2006).

In Nigeria, the TIP is seen as a veritable institutional mechanism for commercialisation of R\&D results. It is an integral support programme designed to assist budding entrepreneurs in the development of new technology-based firms, both start-ups and fledgling ones (FMST, 2005). As earlier mentioned, the Yenagoa TIC is one of the 25 technology incubation centres established in the country. Perhaps, it is the most recent, as its formal take-off was only marked in June, 2008 with setting-up of a temporal office manned by some of its management staff in Yenagoa.

The careful selection of Agudama-Ekpetiama, a suburb of the Yenagoa City that is within proximal distance to all the higher education institutions and research institutes in Bayelsa State [see Figure 2] as the site of the Yenagoa TIC can be considered as one of the first steps in the establishment of the TIC. Such stakeholder institutions will include - the Niger Delta University, Amassoma, the newly established Federal University, Otuoke, Federal Polytechnic, Ekowe, Linnet Paul Innovation Institute, Etegwe-Yenagoa, Niger Delta City Polytechnic, Elebele, the National Centre for Technology Management (NACETEM), Amassoma, Raw Materials Research and Development Council (RMRDC), Yenagoa, Bio-Resources Development Centre, Odi, and other institutions and international as well as national networks of incubators, hence the broken boundaries in Figure 2.

According Polyani (in Cooper, 2006) in developing technology-based ventures, entrepreneurs will draw upon different types of knowledge. Some of such knowledge will be explicit, others tacit. For instance, tacit knowledge - uncodified knowledge which can be exchanged when these technologies "experts" overlap and interact and can further lead to explosive innovation (Barrel, 2004). It is hoped that interactions amongst the various stakeholders in the centre will result in the un-codification of tacit knowledge of the knowledge workers by the introduction of technologies that will add value to product, processes and services.

Since the Yenagoa TIC is still in its infant stages, it will be wise for managers of such facility to learn from the wealth of experience on technology incubation elsewhere in the world so as to make a good first start. Experience can be gained from the abundance of incubation networks, first within the country by reaching out to other TICs. Another way is to connect to well known international incubator organisations such as the National Business Incubators Association of the US, Asian Association of Business Incubations (AABI), National Technology Incubator's Network of Australia (NTIN) among others.

\subsection{Spectrum of technology-business incubators}

Candidate technologies to be considered first in technology-business incubators should include such pervasive technology platforms as ICT, as a global shift from an industrial to knowledge- and information-based economies, driven by revolutionary developments in communication and information technology (Imparato \& Harari in Khota \& Pretorius, 2008). Again, biotechnology as well as agribusiness and perhaps, the plastic industry should be considered because of the abundance of petroleum resources and a proposed refinery and petrochemical industry in Bayelsa State.

\subsection{Objectives of the Yenagoa TIC}

According to the NBIA (2006) two principles characterise effective business incubation and they are: i) the incubator aspires to have a positive impact on its community's economic health by maximizing the success of emerging companies and ii) the incubator itself is a dynamic model of a sustainable, efficient business operation. 
Guided by the same principles like any other incubator, the establishment of the Yenagoa TIC had the following objectives in mind: -

- To design a programme for entrepreneurs;

- To keep them abreast with the latest technology-based products;

- To help in solving specific process problems for client entrepreneurs by continuously injecting innovation in material/manufacturing processing;

- To develop testing and inspection facilities for use by small scale units in collaboration with research centres, government agencies and higher institutions;

- To offer engineering services such as process/production performance, monitoring and improvement as well as general consultancy to client entrepreneurs;

- To liaise with research centres for the production of improved tools for use by the rural artisans for increasing their productivity and earning capacity;

- To foster entrepreneurial culture, by upgrading and enhancing the application of sustainable indigenous technologies to ensure cost effectiveness and optimum production;

- To effectively link talents, technology and capital know-how in order to accelerate the development of new enterprises; and

- To promote economic diversification through the creation of dynamic enterprises in the agro-allied, information and communications technology and manufacturing sectors which will help reduce the country's over dependence on oil (FMST, 2005).

\subsection{Support and services to be provided at the Yenagoa TIC}

UN Millennium Project (2005) states that:

"The over 20 years of experience with business incubators has revealed three critical factors that are important to their success. The first is the creation of the incubator itself and its management. The second is the incubation process. The third is performance assessment".

In like manner, all tenants in the incubator pass through three different stages of incubation process. These are the pre-incubator stage, in which ideas and teams are nurtured; the incubator stage, where business plan is prepared and the post-incubator stage, where enterprises move out to 'grow-on' space (Folinas et al., 2006). The Yenagoa TIC will have to be prepared to provide the needed support structures and services to enable potential tenants grow into to fully fledged business.

The first step is the provision of a physical infrastructure of about $1,500 \mathrm{~m}^{2}$ in size that will provide common workspaces in addition to an array of other services. Knopp (2007) posits that such common services provided by incubators include - help with business basics; networking activities; marketing assistance; high-speed internet access; help with accounting/financial management; access to bank loans, loan funds and guarantee programs; help with presentation skills; links to higher education resources; links to strategic partners; access to angel investors or venture capital; comprehensive business training programs; advisory boards and mentors; management team identification; help with business etiquette; technology commercialization assistance; help with regulatory compliance; and intellectual property management. Others will be - all aspects of insurance, pension planning, recruitment/headhunting, language training and translation/interpretation, corporate and international law, consulting, etc (Barrel, 2004).

However, one of the critical support facilities suggested here is ICT infrastructure with internet network capability. Realising that, in the current new world order has largely become driven by knowledge and exchange of information and ideas with survival in today's information age depending more and more on the ability to use local and international networks (Bubou, 2008). Equally, various support systems and external networks is one of the controlled conditions of incubators (Smilor in Kim \& Ames, 2006). Such will easily facilitate in breaking down the boarders of the incubator and allow incubator tenants benefit from e-coaching/training from other TICs.

\subsection{Benefits}

The development and growth of an incubator unit provides an example of the integration of an initiative into the overall economic development context of an area within a region (McAdam \& Koegh, 2006). Like Schumpeter's (1934) expectations of the entrepreneur in developing new combinations of ideas or resources leading to the 
development of new enterprises to exploit opportunities emerging from technological breakthroughs, the TBI will afford the budding entrepreneur, that rare opportunity to catalyse to full fledged business organisation.

For African countries to promote the development of local technology, they need to review the incentive structures already in place and they must include a range of structures suitable for creating and sustaining enterprises, from taxation regimes and market-based instruments to consumption policies and sources of change in the national system of innovation (Juma, 2006). The structure or strategic orientation of organisations within a region strongly influences the likelihood of future new enterprise creation by indigenous entrepreneurs. Thus, some locations such as Silicon Valley experience significant levels of new technology-based firm formation and as high-technology entrepreneurs tend to exhibit higher educational qualifications than those in other types of firms (Cooper, 2006).

\subsubsection{Rapid industrial growth}

SMEs are expected to lead to the development of new opportunities and the use of technology as most developed and newly industrialising economies around the world relying on them as the drivers of rapid industrialisation (Juma \& Agwara, 2006). The centre shall form a solid foundation for rapid industrialisation and commercialisation process of Bayelsa State by providing collaborative linkages and technology networks with the institutions earlier mentioned to incubate their innovative research findings, as well as indigenous technologies. It will encourage SMEs development by incubating indigenous technologies and scientific innovations from universities and research institutes.

It means incubating firms will engage in technology prospecting which according the UN Millennium Project (2005) entails the searching for, identifying, adapting, and diffusing of imported technology using such technologies that are readily available, adapting them to the local economy; it also entails both research and enterprise development and usually involving creating institutions designed to undertake global searches for technology and find ways of adapting them to local and international markets. This process will greatly enhance the technological capability of the region and the country at large.

Firms which are established in related fields, as service provision opportunities are spotted, are able to serve existing firms and the development of a rich pool of service providers acts not only as a stimulus to enhance local entrepreneurial spin-off activity but also as a magnet to attract footloose entrepreneurs from elsewhere into the area (Cooper, 2006). The researchers believe this was the miracle for emerging economies like India, China, Japan, Korea, Brazil and other developing countries like Malaysia, Singapore, Indonesia and even developed economies of the world.

\subsubsection{Employment generation and wealth creation}

An important research announced by the U.S. Department of Commerce Economic Development Administration (EDA) proves that incubators provide communities with significantly more jobs (as much as 20 times) at far less cost than do any other public works infrastructure projects - including road and bridges, industrial parks, commercial buildings, and sewer and water projects (EDA, 2009). Likewise, when fully functional, the Yenagoa TIC will greatly reduce graduate unemployment, especially graduates of science and engineering disciplines as incubators make significant contribution to job and wealth creation. Youths will be admitted as apprentices/support staff to the budding entrepreneurs to enable them acquire different sets of skill and eventually take-over from their trainers (masters) after graduation within 3 years. This will provides significant multiplier effects in employment generation and wealth creation for our youths.

Since the government of Bayelsa State has been providing funding for the training of youths in ICT related skills abroad, those youths who have been already trained in different in countries like, Cameroon, Russia, Norway, Dubai, India Malaysia and others, will be admitted into the centre as budding entrepreneurs and nurtured into full enterprises at low cost of production due to special subsidies from Federal and State Governments, donor agencies and NGOs.

\subsubsection{Human capacity development}

Human resource development can also be facilitated through skill acquisition and entrepreneurship development of our citizens as apprentices will have the opportunity to be professionally trained in viable skills and become potential entrepreneurs of SMEs.

\subsection{Challenges}

The greatest challenge faced by the Yenagoa TIC is finding funds to kick-start the construction of the facility at Agudama-Eketiama, as all stakeholders have not yet committed their counterpart funds to the centre. This 
situation is not new to the Yenagoa incubators but it is a global phenomenon, especially in developing countries. For instance, Klonowski (2007) observed that the key challenges confronting incubators in developing countries are related to locating capital for their own operations, difficult access to finance by tenants, finding suitable management for investee firms and their own operations, lack of support for SMEs, poor legal and taxation infrastructure, corruption, recruiting suitable staff and 'untested' markets. Like many others, the Yenagoa TIC will have to deal with the challenge of retaining the companies that outgrow the centre, the so-called graduates, in the region or even country (Stefanovic et al., 2008).

Another major challenge will be creating links between knowledge generation and business development as this has been one major challenge faced by African countries generally (Juma, 2006). Especially, in Nigeria, it has really been difficult to commercialise knowledge and ideas from researchers in the countries universities and other research institutes to value added innovative products, processes and services.

\section{Conclusions}

This exploratory case study has exposed to a reasonable extent how the concept of technology-business incubation can be applied to fast-track the technological advancement of regions and countries, especially developing countries. The paper also confirms that TBIs will help the start-up of enterprises, especially in the technology sector with its attendant benefits of employment generation, technology prospecting. This will lead to technology transfer both domestic and cross-national boarders and will ultimately lead to regional development. Besides, it also portends as veritable poverty reduction tool because of its multiplier effects of job and wealth creations and in the particular case of Bayelsa State, it may also help stem youth's restiveness which has become a major crisis of international proportions.

But real incubation and acceleration requires engagement with the people by skilled and experienced business people who have "been there and done it and the support structures must be developed to assist creation of start-ups (Barrel, 2004). However, state support is not just implementing a set of policies that succeed elsewhere, it is the ability of the state to set up institutions that reflect a harmony between knowledge and physical infrastructure and the formal and informal institutional compensations that are important to them, and structure the idiosyncratic exchange processes of developing economies (Oyelaran-Oyeyinka \& Sampath, 2009). More so, a success model cannot be copied too mechanically (De Beule \& Van Beveren, 2008). Therefore, it requires further studies to ascertain the peculiarities of the host region so as to ensure a perfect match between the philosophy behind the establishment of the TIC and the realities on ground.

This call may not have come in a better time that this, as Bayelsa State is set to witness the development of major highly technology-intensive industries like the Refinery and Petrochemical Project, the Green Field export oriented Refinery as well as the Brass liquefied natural gas (LNG) Project. The Yenagoa TIC will prepare the people to adequately avail themselves of the business opportunities that will ensue. When such happens, the current situation of poverty and underdevelopment will be tackled, leading to improved socio-economic conditions of the people. As earlier noted, the results from this model can be duplicated elsewhere, especially within the Niger Delta region of Nigeria which share similar characteristics.

\section{References}

Barrel, A. (2004). Innovation Champions Network: The Cambridge Cluster Description. [Online] Available: http://www.insme.org/documents/montrealStruct.pdf (June 12, 2011).

Bozeman, B. (2000). Technology transfer and public policy: a review of research and theory. Research Policy. 29 (2000), 627-655. http://dx.doi.org/10.1016/S0048-7333(99)00093-1

Bubou, G. M. (2008), Shifting paradigms in education: imperatives for the integration of ICT into Bayelsa State's educational system. [Online] Available: http://ssrn.com/abstract=1282722

Bubou, G. M. \& Egai, N. A. (2010). Entrepreneurship development as a sustainable poverty reduction strategy: a case for the People of the Niger Delta. In proceedings of the $2^{\text {nd }}$ International Conference on Natural Resource, Security \& Development in the Niger Delta, March 8 - 11, 2010, Wetland Centre, Yenagoa, Bayelsa State, organised by the Department of Political Science, Niger Delta University, Bayelsa State, Nigeria and the Department of Geosciences, University of Missouri-Kansas City, United States of America.

Bubou, G. M. \& Siyanbola, W. O. (2010). 'Science and Technology Entrepreneurship for Socio-Economic Development in Africa (SEEDA)', In proceedings of the Third Annual International Conference on Entrepreneurship organised by WITS Business School, University of Witwatersrand, Johannesburg, South Africa, October 20 - 21, 2010. 
Cooper, D. R. \& Schindler, P. S. (2003). Business Research Methods (8th ed.), New York: McGraw Hill.

Cooper, S. (2006). Knowledge and expertise for high-technology entrepreneurship: a tale of two sectors. International Journal of Knowledge Management Studies. 1 (1/2), 59-78. http://dx.doi.org/10.1504/IJKMS.2006.008845

De Beule, F. \& Van Beveren, I. (2008). Production and renewal: foreign firms and clusters in Belgium. LICOS Centre for Institutions and Economic Performance, LICOS Discussion Paper No. 227/2008. [Online] Available: http://ssrn.com/abstract=1343562 (February 17, 2009).

EDA. (2009). 'Construction Grants Program Impact Assessment Report', prepared by Grant Thornton for the U.S. Department of Commerce Economic Development Administration and announced in a January 2009, EDA Newsletter

FMST (2005). Technology Incubation Programme in Nigeria: Policy, Functions, Structures and Operational Guidelines. Abuja: Federal Ministry of Science and Technology

Folinas, D., Pastos, P., Manthou, V. \& Vlachopoulou, M. (2006). Virtual Pre-Incubator: a new entrepreneurship approach. International Journal of Enterprise Network Management. 1 (1), 29-40. http://dx.doi.org/10.1504/IJENM.2006.010064

Grimaldi, R. \& Grandi, A. (2005). Business incubators and new venture creation: an assessment of incubation models. Technovation. 25, 111-121. http://dx.doi.org/10.1016/S0166-4972(03)00076-2

Jordan, R., Kassicieh, S., Roldán, A, Jerez, N., Lotufo, R. \& Murphy, R. (2006). Science and technology entrepreneurship for economic development (SEED). In proceedings of the $9^{\text {th }}$ International Conference on Engineering Education, San Juan, PR, 23 - 28 July, 2006

Juma, C. (2006). Reinventing growth: science, technology and innovation in Africa. International Journal of Technology and Globalisation. 2 (3/4), 323-339. http://dx.doi.org/10.1504/IJTG.2006.011920

Juma, C. \& Agwara, H. (2006). Africa in the global knowledge economy: strategic options. International Journal of Technology and Globalisation. 2 (3/4), 218-231. http://dx.doi.org/10.1504/IJTG.2006.011911

Kark, B. L. (2003). The Evolutionary process of venture incubation in Korea. Journal of Entrepreneurship and Innovation Management. 3, 78-86. http://dx.doi.org/10.1504/IJEIM.2003.002220

Khanduja, D., Khanduja, J. \& Singh, S.S. (2008). The ambience of incubated entrepreneurship in Indian economy', South East Asia, Australia and New Zealand (SEAANZ) 2008 Conference Proceedings. [Online] Available: http://wms-soros.mngt.waikato.ac.nz/NR/seaanz/docs/proceedings/677.pdf (February 18, 2011)

Khota, I. A. \& Pretorius, L. (2008). Embedded innovation - strategic management incubators for knowledge hegemony. South African Journal of Industrial Engineering. 19 (1), 105-118.

Kim, H. \& Ames, M. (2006). Business incubators as economic development tools: rethinking models based on the Korea experience. International Journal Technology Management. 33 (1), 1-24. http://dx.doi.org/10.1504/IJTM.2006.008189

Kirwan, P., van der Sijde, P. \& Klofsten, M. (2008). Supporting high-tech companies reaching the business platform: about the role of training, coaching and networking. International Journal of Innovation and Regional Development. 1 (1), 48-65. http://dx.doi.org/10.1504/IJIRD.2008.016859

Klonowski, D. (2007). High-tech incubators in transition economies: a case study of iPark, a venture capital backed internet holding company. International Journal of Technoentrepreneurship. 1 (1), 21-34. http://dx.doi.org/10.1504/IJTE.2007.013269

Knopp, L. (2007). 2006 State of the Business Incubation Industry. Ohio: NBIA Publications, Athens.

Ma, F. L. (2004). Incubators in China and the Development of Private Sector. New Delhi: Global Forum on Business Incubation.

McAdam, R. \& Keogh, W. (2006). Incubating enterprise and knowledge: a stakeholder approach. International Journal of Knowledge Management Studies. 1 (1/2), 103-120. http://dx.doi.org/10.1504/IJKMS.2006.008848

Mellati, A. (2008). Technology, trade specialisation and development: jumping to technology development era', A Paper Presented at the 7th APEF International Conference on East and West Asia Trade and Economic Relations: Opportunities, Challenges and Outcomes, Iran.

NBIA. (2009a). The history of business incubation. [Online] Available: http://www.nbia.org/resource_center/what_is/beginnings_of_inc/index.php (December 7, 2010) 
NBIA. (2009b). Tips for Developers. [Online] Available: http://www.nbia.org/resource_center/developers_tips/index.php (December 7, 2010).

NBIA. (2008). Business incubation facts. [Online] Available: http://www.nbia.org/resource_center/bus_inc_facts/index.php (December 7, 2010).

NBIA. (2006). Principles and best practices of business incubation. [Online] Available: http://www.nbia.org/resource_center/best_practices/index.php (December 7, 2010).

NTIN. (2009). Input on National Innovation System. [Online] Available: www.innovation.gov.au/innovationreview/Documents/236_NTIN.pdf (December 6, 2010).

Oyelaran-Oyeyinka, B. \& Lal, K. (2006). Learning new technologies by small and medium enterprises in developing countries. Technovation. 26, 220-231. http://dx.doi.org/10.1016/j.technovation.2004.07.015

Oyelaran-Oyeyinka, B. \& Sampath, P. G. (2009). The state and innovation policy in late development: evidence from South Africa and Malaysia. International Journal of Technological Learning, Innovation and Development. 2 (3), 173-192.

Page, C. \& Meyer, D. (2000). Applied and Research Design for Business and Management. Sydney: Irwin/McGraw-Hill.

Raghavendra, N. V. \& Bala Subrahmanya, M. H. (2006). Development of a measure for technological capability in small firms. International Journal of Innovation and Learning. 3 (1), 31-44. http://dx.doi.org/10.1504/IJIL.2006.008178

Sankat, C. K. (2010). Science, technology, innovation and entrepreneurship - Trinidad and Tobago's vision for development. [Online] Available: http://worldsustainable.org/index.php/papers/413-sankat (August 5, 2010).

Reynolds, P. D., Hay, M. \& Camp, S. M. (1999). Global Entrepreneurship Monitor - 1999 Executive Report. The Global Entrepreneurship Monitor.

Saunders M., Lewis P. \& Thornhill A. (1997). Research methods for business students (3rd Ed.). London: Pitman Publishing.

Schumpeter, J. A. (1934). The Theory of Economic Development. Cambridge, Massachusetts: Harvard University Press.

Southwood, R. (2004). African ICT incubators: breeding new businesses and spreading innovation. [Online] Available: http://www.balancingact-africa.com/news/back/balancing-act_186.html (January 18, 2011).

Stefanovic, M., Devedžic, G. \& Eric, M. (2008). Incubators in Developing Countries: Development Perspectives. International Journal for Quality Research. 2 (3), 157-163.

UN Millennium Project. (2005). Innovation: Applying Knowledge in Development. Task Force on Science, Technology, and Innovation. London: Earthscan Publishing.

Wikipedia. (2009). Business incubator. [Online] Available: http://en.wikipedia.org/wiki/Business_incubators (December 23, 2009). 


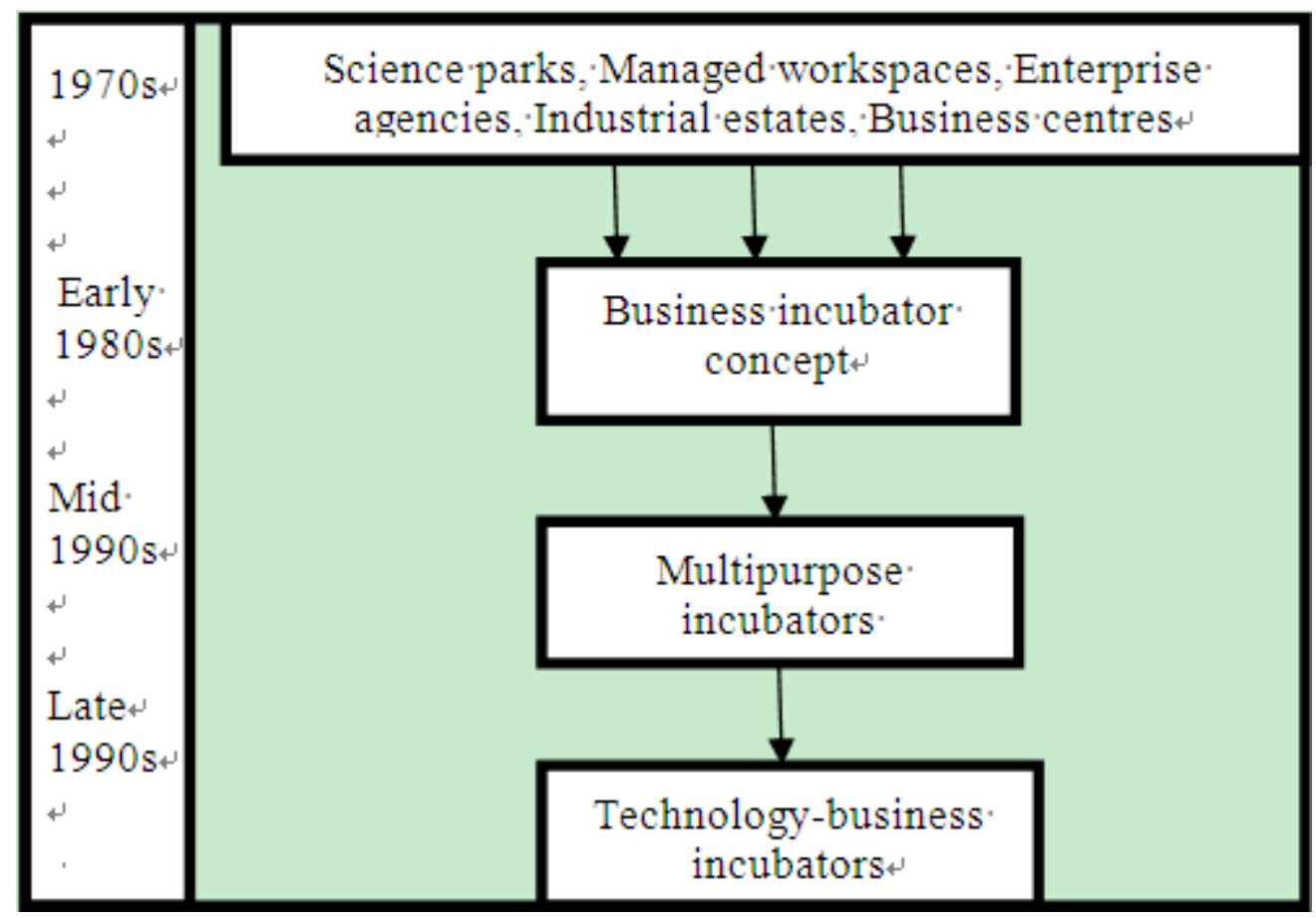

Figure 1. The evolution of TBIs

Source: Adapted from Folinas et al., 2006

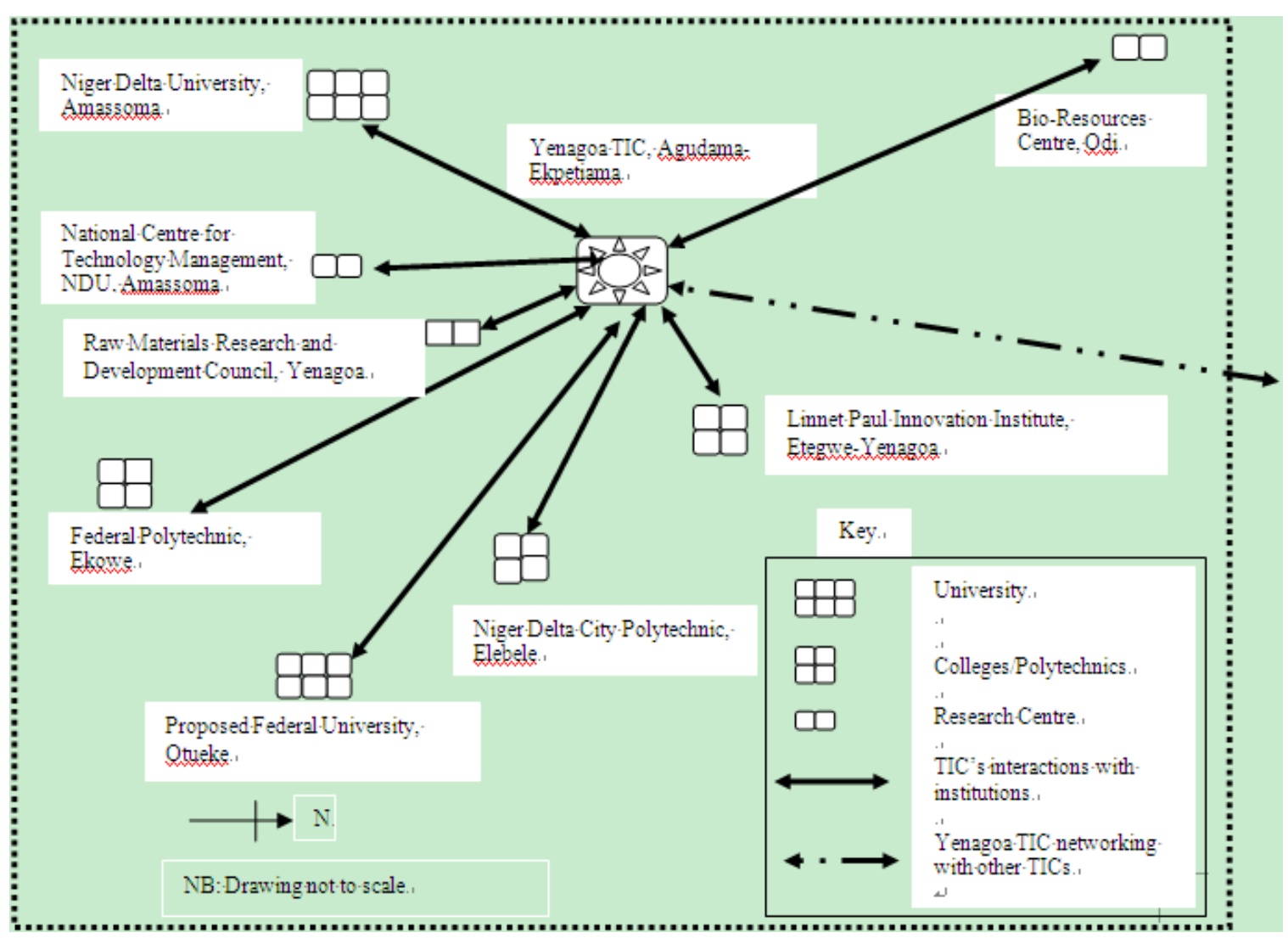

Figure 2. Yenagoa TIC and its network of higher institutions and research centres 